UDC 614.82

\title{
NORMATIVE REGULATION OF EMPLOYMENT OF STUDENTS ON DAY STUDYING FORM
}

\author{
L. E. Piskunova, T. O. Zubok, B. V. Kislytsky
}

National University of Life and Environmental Sciences of Ukraine, Ukraine.

Corresponding authors: voynalov@bigmir.net.

Article history: Received: March 2019. Received in the revised form: April 2019. Accepted: May 2019. Bibl. 23, fig. 0, tabl. 0

Abstract. Some of the most widespread situations are discussed, which in practice often raise the question: to take a student of full-time part-time or consider the company as the main place of his work, who and how will conduct a work book. During studying between full-time students and educational institutions, there is no employment relationship and no employment contract. Therefore, such training is not the main work of the student. Minor student workers have the same labor rights and responsibilities as other employees.

Key words: the Labor Code of Ukraine, the State Department for Labor Legislation Supervision, the Instruction on the procedure for conducting labor books, labor legislation, work under an employment contract, a work book, a combination of work, a monetary expression, the employment of minors.

\section{Introduction}

Human life is inextricably linked with learning. The latest technologies, which are constantly being introduced into production, the development of science and technology, put forward rigorous requirements for the education and qualification of modern workers.

\section{Formulation of problem}

Today the situation when a student begins to work before the end of an educational institution or an employee of an enterprise obtains education or increases qualification without leaving the production is already a norm. Also, considering the socio-economic situation in the country, when parents are no longer able to help children-students, young people are forced to seek for a work. And more and more often there are issues of a law nature regarding to the regulation of labor relations with students who combine work with study. The proper execution of documents, observance of the right to privileged working conditions, determined by the current legislation, is the key to the successful acquisition by an employee of a proper education. It should be noted here that it is not always a cursory reading of the provisions of normative acts that makes it possible to understand how the employer should act in order to ensure the right of an employee to education.

\section{Purpose of research}

The purpose of the paper is to consider some of the most common situations, which in practice often raise questions. It is connected with an explanation regarding the normative regulation of the employment of full-time undergraduate students, which existed during the last ten years.

\section{Results of research}

The first question that arises immediately is to take a student of full-time for a part-time or consider the company as the main place of his work. The question is fundamental, as it is related to the conduction of a work book.

The clarifications provided by the State Department for the Supervision of Compliance with Labor Law have changed year by year. In its letter dated August 8, 2002 No. 010-777, the Department substantiates the position that full-time students can be hired only on a conditional basis. This opinion is based on the Law of Ukraine "On Employment of the Population" of March 1, 1991, No. 803-XII, stipulating that persons studying at secondary schools and higher educational establishments are in work persons.

Based on the latest explanations of the normative regulation of the employment of day-care students, conclusions can be drawn.

The current labor law does not contain a definition of the concept of the main place of work or part-time work. However, the work of a student who attends full-time study forms can not be considered as part-time. As for full-time students, during the training between them and educational institutions there is no employment relationship and no employment contract. Therefore, such training is not the main work of the student.

Minor student workers have the same labor rights and responsibilities as other employees. However, when employing first-year students, employers must monitor whether there are among them minors who need to have special employment and labor requirements.

The first question that arises immediately is to take a student of full-time study for a part-time work or to consider the company as the main place of his work. The question is fundamental, since it is connected with the conduct of the labor book (or work book), and the Code of Labor Laws of Ukraine (hereinafter - the Labor Code) not 
only does not give a concrete answer, but does not mention it at all.

Clarifications provided by the State Department for the Supervision of Compliance with the Labor Law (hereinafter - the Department) changed year by year. Thus, in its letter dated August 8, 2002 No. 010-777, the Department substantiates the position that full-time students can be hired only on a conditional basis. This opinion is based on such considerations.

The Law of Ukraine "On Employment of the Population" of March 1, 1991, No. 803-XII stipulates that persons studying in secondary schools and higher educational establishments are in work persons.

According to Part 1 of Article 48 of the Labor Code, the main document confirming the work of an employee is his work book. Precisely where the work book is handled, it is clear is it the main place of work of an employee or the place of his work on terms of a combination. In this case, the fact of receiving or not receiving remuneration for the performance of certain duties is not taken into account.

Part 2 of Article 24 of the Labor Code stipulates that when entering into an employment contract a citizen is obliged to submit a passport or other document certifying a person, a work book, and in cases stipulated by the legislation - also a document on education (specialty, qualification), the status health and other documents.

In accordance with the clause 1.4 of the Instruction on the procedure for conducting labor records of workers approved by the order of the Ministry of Labor of Ukraine, the Ministry of Justice of Ukraine, the Ministry of Social Protection of the Population of Ukraine of July 29, 1993 No. 58 (hereinafter referred to as the Instruction), persons who are first employed and not have a work book, must present a passport, diploma or other document on education or vocational training, that is, a document confirming the fact of completion of the training process. The certificate about the fact of studying at an educational institution is not a document about education, as it does not certify the completion of the educational process, that is deductions from the educational institution.

A full-time student can not present a certificate of education, because he is kept in his personal affairs, which is conducted by an educational institution. Consequently, the employer can not arrange him a work book, that is, he can not conclude an employment contract with a principal employee.

However, in a letter dated August 20, 2003, No. 013 1229-22, the Department determines that the recruitment of students in the field offices of higher educational institutions is not a combination. Thus, the enterprise is considered to be the main place of work of the student, and the conduct of a work book should be carried out on a general basis. Another argument in favor of the student's registration as a main place of work may be the resolution of the Plenary Session of the Supreme Court of Ukraine "On the Practice of the Use by the Courts of the Law on the Payment of Labor" of December 24, 1999, No. 13, the third paragraph of paragraph 14 of which states: "Work under an employment contract of persons, who combine it with a full-time form of study, are not part-time and paid for on a general basis. " However, the Department expressed the opinion that this resolution does not have the status of normative legal act, and the action of paragraph 14, based on the name of the ruling, extends to the issue of remuneration, rather than the employment contracts with persons who combine work with full-time education.

The question would not be so ambiguous if universities were obliged to keep work books (if any) or to open them to students who did not have a seniority before entering the university. Therefore, each educational institution decides the question about presentation of a work book: some require it from the students (if any), while others are not interested at all whether the student worked before entering the university and whether he has a work record.

Based on the latest explanations, normative regulation of employment of full-time students, we can draw conclusions.

Article 43 of the Constitution of Ukraine defines the right of every citizen to work, including the possibility of earning for a living by some work, which he freely chooses or freely agrees to. In accordance with Article 2 of the Labor Code, the state guarantees the right of citizens to work. For the work performed by the employee (citizen), the owner or his authorized body pays his salary - a remuneration, calculated, as a rule, in monetary terms (Article 94 of the Labor Code, Article 1 of the Law "On Labor" dated March 24, 1995, No. 108/95 -BR).

In sp. 7 clause 1 of Art. 1 Law of Ukraine "On Employment of the Population" dated 05.07.2012 No. 5067-VI (hereinafter - the Law № 5067-VI) stipulates that employment is not prohibited by the law the activities of persons connected with the satisfaction of their personal and social needs in order to receive income (wages) in monetary or other form. And according to Part 1 of Art. 4 Publication No. 5067-VI also covers the number of fulltime students enrolled in higher education and combines studying with the work. In addition, the Law of Ukraine "On Education" dated May 23, 1991 No. 1060-XII (Part 14, Clause 1, Article 51) and the Law of Ukraine "On Higher Education" dated July 1, 2014, No. 1556-VII (clause 3, p. 1 item 62) students have the right to work in accordance with the established procedure at extracurricular time.

The current labor law does not contain a definition of the concept of the main place of work or part-time work. However, the work of a student who attends full-time study forms cannot be considered as part-time. After all, in accordance with clause 1 of the Regulations on the conditions of work of the part-time employees of state enterprises, institutions and organizations, approved by a joint order of the Ministry of Labor, Ministry of Justice and the Ministry of Finance of 28.06.1993 number 43, parttime is considered to be, except employees main, other regular paid work on the terms of an employment contract, the time off from the main work at the same enterprise, institution, organization or citizen (entrepreneur, private person) for hire.

The right to work of an employee is realized through the conclusion of an employment contract on work in an enterprise, an institution, an organization or an individual (Article 2 of the Labor Code). As for full-time students, during the studying, between them and educational institutions there is no employment relationship and no employment contract. Therefore, such studying is not the main work of the student. Consequently, his work (in the 
case of employment) cannot be regarded as being performed in addition to his main work, that is, a combination. In addition, the position that the work of an employment contract of persons who combine it with a full-time form of study is not a part-time, is set forth in the letter of the Ministry of Social Policy from 05/25/2015 № $198 / 06$ / 186-15. It actually referred to paragraph 3 of paragraph 14 of the Verkhovna Rada of Ukraine "On the Practice of the Use of Labor Legislation by the Courts" of December 24, 1999, No. 13, which stipulates that work under an employment contract of persons who combine it with a full-time form of study, is not part-time and is paid on a general basis. The same position is set out in the letter of the Ministry of Social Policy of Ukraine dated July 25, 2014 № 301/13 / 116-14 concerning the recruitment of students. It states, in particular, that labor laws do not provide restrictions on the combination of university students, including those studying in full-time forms of study, work and education. Therefore, the employer has the right to employ such employees, including on a full-time basis. Consequently, the work through an employment contract of persons who combine it with full-time education is not a part-time job, and therefore involves keeping a work record in accordance with the general procedure and is the main place of work for such persons.

We want to stay isolated on the employment of minors. Students-workers have the same labor rights and responsibilities as other employees. However, when employing first-year students, employers must monitor whether there are among them minors who need to have a special employment and labor requirements. The work of minors, namely persons under the age of 18, is regulated, in particular, by the norms of Art. 187-200 Labor Code. When hiring a specified category of employees should be taken into account that Art. 51 Labor Code provides the establishment of a shorter working hours (36 hours per week) for workers, including students aged 16 to 18 years, as well as those employed in work with harmful and difficult working conditions. At the same time, it should be noted that a student who studies in a permanent (special) department of an educational institution can perform his / her duties only during his / her free time: on weekdays after classes (in the evening or during "windows" in the schedule of classes), on weekends or during the holidays.

\section{Conclusions}

Students who are studying on an individually defined schedule must make sure that there is no "overlap" with the time of individual studying or examinations. In Part 1 of Art. 56 of the Labor Code defines that an agreement between the employee and the owner or the body authorized by him may be established both during hiring and subsequently part-time or part-time working weeks, and in Part 2 of this article it is established that wages in these cases is carried out in proportion to the time worked or depending on the output. That is, the mode of work of students will depend on the schedule of studying, and the payment of labor - on the duration of the performance of the labor duties.

\section{References}

1. The Law of Ukraine "On Occupational Safety" in the wording of November 21, 2002.

2. The Law of Ukraine "On Compulsory State Social Insurance against Accident at Work and Occupational Disease that Caused Disability".

3. Legislation of Ukraine on labor protection (a collection of normative documents., $4 \mathrm{t}$. - $\mathrm{K}$.: State Committee of Ukraine for Supervision of Labor Protection, Osnova, 1995.

4. The Law of Ukraine "On Education" No. 1060-XII of 23.05.1991 (subparagraph 14, paragraph 1, Article 51) and the Law of Ukraine "On Higher Education" dated July 1, 2014, No. 1556-VII (paragraph 3 of clause 1 Article 62)

5. Law of Ukraine "On Employment of the Population" of 1 March 1991 No. 803-XII.

6. Article 15 of the Law of Ukraine "On Vacations" dated November 15, 1996 No. 504/96-VR).

7. The Code of Labor Laws of Ukraine (Revision of 10.11.2018, basis -2542-VIII).

(Article 2, Part 2 of Article 24, Articles 38, 39, 40, Part 1, Article 48, Article 50, Article 51, Part 1, Article 56, Article 94, Article 187- 200; st.201-204;) st.216-217; p.6 pp. 1 pp. 232; Part 6 of the Art. 235,238.

8. Art. 1 3У "About payment of labor" dated March 24, 1995, № 108/95-BP).

Part 1 of Art. 4 lesson № 5067-VI

9. pp. 7 clause 1 of Art. 1 Law of Ukraine "On Employment of the Population" dated 05.07.2012 No. 5067-VI (hereinafter - the Law № 5067-VI)

10. Letter of the Ministry of Social Policy of 05.05.2015 № 198/06 / 186-15.

11. Letter of the Ministry of Social Policy of Ukraine dated July 25, 2014 № 301/13 / 116-14

12. Letter from the State Department for Supervision of Compliance with the Labor Law of August 8, 2002, No. 010-777.

13. Clause 1.4. Instruction on the procedure for conducting work books of workers (approved by the order of the Ministry of Labor of Ukraine, Ministry of Justice of Ukraine, Ministry of Social Protection of the Population of Ukraine dated July 29, 1993 No. 58)

14. Letter from the State Department for Supervision of Compliance with the Labor Law of August 20, 2003 No. 013-1229-22

15. Resolution of the Plenary Session of the Supreme Court of Ukraine "On the Practice of the Application by the Courts of Labor Payments Legislation" of December 24, 1999, No. 13.

16. Part 3, Clause 14 of the Resolution of the Supreme Court of Ukraine "On the Practice of the Use by the Courts of the Law on Remuneration of Work" of December 24, 1999, No. 13.

17. Resolution of the Cabinet of Ministers of Ukraine dated 28 June 1997. No. 634 "On Approval of the Procedure, Duration and Conditions for the Provision of Annual Vacations for Workers Studying at Higher Educational Institutions with Evening and Extramural Forms of Education, where the educational process has its own peculiarities"

18. State sanitary norms and rules "Hygienic classification of labor on the indicators of harmfulness and 
danger factors of the production environment, the severity and intensity of the labor process", approved by the order of the Ministry of Health of Ukraine from 08.04.2014 number 248.

19. Order of the Ministry of Health of Ukraine of 25.05.2006 № 319 .

20. Order of the Ministry of Labor and Social Policy of Ukraine dated March 23, 2001 №122

21. The procedure for the certification of workplaces under the terms of work, approved by the Cabinet of Ministers of Ukraine from 01.08.92, No. 442.

22. https://www.sop.com.ua/article/654-triandidrobochogo-chasu?utm_source=Email\&utm_medium $=$ letternews\&utm_campaign=letternews_SOP02032018\&u $\mathrm{stp}=\mathrm{F}$

23. Fundamentals of labor protection: the textbook / Zaporozhets O.I.; ed. prof. OI Zaporozhets - Kyiv: Publishing Center of the Central Library, 2018. 264 p.

\section{Список літератури}

1. Закон України "Про охорону праці" в редакції від 21 листопада 2002 р.

2. Закон України "Про загальнообов'язкове державне соціальне страхування від нещасного випадку на виробництві та професійного захворювання, які спричинили втрату працездатності".

3. Законодавство України про охорону праці (збірник нормативних документів. У 4 т. - К.: Держнаглядохоронпраці; Основа, 1995.

4. Законом України «Про освіту» від 23.05.1991 № 1060-XII (ч. 14 п. 1 ст. 51) та Законом України «Про вищу освіту» від 01.07.2014 № 1556-VII (пп. 3 п. 1 ст. 62)

5. Законом України «Про зайнятість населення» від 1 березня 1991 р. № 803-XII

6. ст. 15 Закону України «Про відпустки» від 15 листопада 1996 р. № 504/96-ВР).

7. Кодекс законів про працю України (Редакція від 11.10.2018, підстава - 2542-VIII)

(ст. 2 ; ч. 2 ст. 24 ; ст. $38,39,40$; ч. 1 ст. 48 ; ст. 50 ; ст. 51 ; ч. 1 ст. 56 ; ст. 94; ст. 187-200; ст.201-204; ) ст. 216-217; п.6 ч. 1ст. 232 ; ч. 6 ст. 235,238 .

8. ст. 1 ЗУ «Про оплату праці» від 24.03.1995 № 108/95-BP).

ч. 1 ст. 4 ЗУ № 5067-VI

9. пп. 7 п. 1 ст. 1 ЗУ «Про зайнятість населення» від 05.07.2012 № 5067-VI (далі - ЗУ № 5067-VI )

10. Лист Мінсоцполітики від 25.05.2015 № 198/06/186-15.

11. Лист Мінсоцполітики від 25.07.2014 № 301/13/116-14

12. Лист Державного департаменту нагляду за додержанням законодавства про працю від 8 серпня 2002 p. № 010-777.

13. п. 1.4 Інструкція про порядок ведення трудових книжок працівників( затвердженої наказом Міністерства праці України, Міністерства юстиції України, Міністерства соціального захисту населення України від 29 липня 1993 р. № 58)
14. Лист Державного департаменту нагляду за додержанням законодавства про працю від 20 серпня 2003 р. № 013-1229-22

15. Постанова Пленуму Верховного Суду України «Про практику застосування судами законодавства про оплату праці» від 24 грудня 1999 р. № 13.

16. ч.3 п.14 постанови Верховного Суду України «Про практику застосування судами законодавства про оплату праці» від 24.12.1999 № 13.

17. Постанова Кабінету Міністрів України від 28 червня 1997 р. № 634 «Про затвердження Порядку, тривалості та умов надання щорічних відпусток працівникам, які навчаються у вищих навчальних закладах з вечірньою та заочною формами навчання, де навчальний процес має свої особливості»

18. Державні санітарні норми та правила «Гігієнічна класифікація праці за показниками шкідливості та небезпечності факторів виробничого середовища, важкості та напруженості трудового процесу», затверджені наказом МО3 України від 08.04.2014 № 248 .

19. Наказ Міністерства охорони здоров'я України від 25.05.2006 № 319 .

20. Наказ Міністерства праці та соціальної політики України від 23.03.2001 №122

21. Порядок проведення атестації робочих місць за умовами праці, затвердженого постановою Кабінету Міністрів України від 01.08.92 № 442.

22. https://www.sop.com.ua/article/654-trivalstrobochogo-chasu?utm_source=Email\&utm_ medium=letternews\&utm_campaign=letternews_SOP020 $32018 \&$ ustp $=\mathrm{F}$.

23. Основи охорони праці: підручник /Запорожець O.I; за ред. проф. О.I. Запорожця. Київ: Видавничий центр ЦУЛ, 2018. 264 с.

\section{НОРМАТИВНЕ РЕГУЛЮВАННЯ ПРАЦЕВЛАШТУВАННЯ СТУДЕНТІВ, ЩО НАВЧАЮТЬСЯ НА ДЕННОМУ ВІДДІЛЕННІ \\ Л. Е. Піскунова, Т. О. Зубок, Б. В. Кислицький}

Анотація. Розглянуто кілька поширених ситуацій, які на практиці найчастіше викликають питання: приймати студента денної форми за сумісництвом, вважати підприємство основним місцем його роботи, хто і як буде вести трудову книжку. Під час навчання між студентами денної форми навчання та навчальними закладами не виникають трудові відносини і не укладається трудовий договір. Тому таке навчання не $\epsilon$ основною роботою студента. Неповнолітні студенти-працівники мають такі ж трудові права і обов'язки, як і інші працівники.

Ключові слова: Кодекс законів про працю України, Державний департамент нагляду за додержанням законодавства про працю, Інструкції про порядок ведення трудових книжок, трудове законодавство, робота за трудовим договором, трудова книжка, сумісництво, грошовий вираз, працевлаштування неповнолітніх. 
НОРМАТИВНОЕ РЕГУЛИРОВАНИЕ

РАБОТОУСТРОЙСТВА СТУДЕНТОВ, КОТОРЫЕ

УЧАТЬСЯ НА ДНЕВНОМ ОТДЕЛЕНИИ

Л. Е. Пискунова, Т. О. Зубок, Б. В. Кислицкий

Аннотация. Рассмотрены несколько распространённых ситуаций, которые на практике чаще всего вызывают вопрос: принимать студента дневной формы по совместительству, считать предприятие основным местом его работы, кто и как будет вести трудовую книжку. Во время учёбы между студентами дневной формы обучения и учебными заведениями не возникают трудовые отношения и не заключается трудовой договор. Поэтому такое обучение не является основной работой студента. Несовершеннолетние студенты-работники имеют такие же трудовые права и обязанности, как и другие работники.

Ключевые слова: Кодекс законов о труде Украины, Государственный департамент надзора за соблюдением законодательства о труде, Инструкции о порядке ведения трудовых книжек, трудовое законодательство, работа по трудовому договору, трудовая книжка, совместительство, денежное выражение, трудоустройство несовершеннолетних.

L. E. Piskunova ORCID 0000-0002-0317-7683.

T. O. Zubok ORCID 0000-0003-2612-6077.

B. V. Kislytsky ORCID 0000-0003-0636-4748. 
